\title{
New Data on the Distribution and Conservation Status of the Two Endemic Scrapers in the Turkish Mediterranean Sea Drainages (Teleostei: Cyprinidae)
}

Kaya $\mathrm{C}^{1 *}$, Kucuk $\mathrm{F}^{2}$ and Turan $\mathrm{D}^{1}$

${ }^{1}$ Recep Tayyip Erdogan University, Turkey

2Isparta University of Applied Sciences, Turkey

*Corresponding author: Cuneyt Kaya, Faculty of Fisheries and Aquatic Sciences, Recep Tayyip Erdogan University, 53100 Rize, Turkey, Tel: +904642233385; Email: cnytkaya@yahoo.com

\section{Research Article}

Volume 2 Issue 6

Received Date: October 31, 2019

Published Date: November 13, 2019

DOI: $10.23880 /$ izab- 16000185

\section{Abstract}

In the scope of this study, exact distribution of the two endemic Capoeta species in the Turkish Mediterranean Sea drainages was presented. Fishes were caught with pulsed DC electro-fishing equipment from 28 sampling sites throughout Turkish Mediterranean Sea drainages between Göksu River and stream Boğa. The findings of the study demonstrate that Capoeta antalyensis inhabits in Köprüçay and Aksu rivers, and streams Boğa and Gündoğdu, all around Antalya. Capoeta caelestis widely distributed in coastal stream and rivers between Stream Dim (Alanya) in the west and Göksu River (Silifke) in the east. Metric and meristic characters were collected from the fish samples which obtained in the field for Capoeta caelestis and Capoeta antalyensis, and museum material for Capoeta damascina. In this way, morphologic features of the species revealed and Capoeta caelestis compared with Capoeta damascina to remove the hesitations about the validity of the species. The conservation status of Capoeta antalyensis was recommended to uplist from Vulnerable to Endangered.

Keywords: Freshwater Fish Species; Anatolia; Pisces; Capoeta antalyensis; C. caelestis

\section{Introduction}

Capoeta is one of the most widespread genus in Anatolia. The diversity in the genus in Turkey has been studied intensively in the last 15 years by the both molecular and taxonomic studies [1-15]. Among these studies, Turan [5] examined mitochondrial 16S rDNA gene sequences in order to reassess the taxonomic status of Capoeta species in Anatolia. According to his findings; $C$. antalyensis, C. barroisi, C. damascina, C. pestai, C. tinca and $C$. trutta are valid species, as well as there are four subspecies of $C$. capoeta (C. c. angorae, C. c. bergamae, C. c. capoeta and C. c. sieboldii). Turan [5] also suggested that Göksu River and Dalaman Stream populations are belong 


\section{International Journal of Zoology and Animal Biology}

to two new species that have not yet been named. Subsequently, Schöter, et al. [7] identified Göksu River populations as C. caelestis. Recently, Dalaman River populations have been identified as $C$. aydinensis with populations inhabit in Tersakan, Namnam and Büyük Menderes River [4]. Alwan [15] and Alwan, et al. [16] conclusively demonstrated that $C$. angorae from the Seyhan and Ceyhan is a synonym of $C$. damascina, this view also supported by following molecular and taxonomic studies $[4,9,11-13,17]$.

Küçük \& Güçlü [18] reported C. antalyensis between Peri Village (near Gündoğdu-Manavgat, Antalya) and stream Boğa (almost the westernmost side of the Antalya city).

According to the studies mentioned above, Capoeta antalyensis is known from stream and rivers around Antalya, and C. caelestis is known from Göksu River (near Silifke, Mersin) where it was described first and some coastal streams between Antalya and Göksu River. Here, we checked streams and rivers draining to Turkish Mediterranean Sea to determine the exact distribution range of the both species.

On the other hand, Özdemir [10] reported that Capoeta caelestis is taxonomically close to C. damascina and there is confusion in the taxonomic situation of this species. Her claim triggered us to evaluate the taxonomic validity of $C$. caelestis and compare it with $C$. damascina.

\section{Material and Methods}

Fishes were caught with pulsed DC electro-fishing equipment from 28 sampling sites throughout Turkish Mediterranean Sea drainages between Göksu River and stream Boğa (Figure $1 \&$ Table 1). After anastesia, fish samples were fixed in $4 \%$ formalin and transferred to the laboratory for classify at species level. Measurements were made using a dial calliper $(0.1 \mathrm{~mm})$. All measurements were made point-to point, never by projections. Meristic counts and measurements follow Kottelat \& Freyhof [19] and Kaya [14]. The map (Figure 1) was created using the Qgis v. 2.6.1-Brighton software available at http://divagis.org.

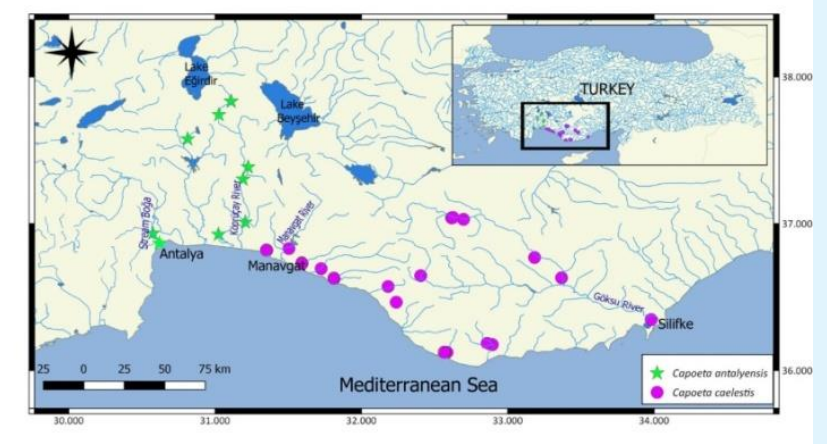

Figure 1: Distribution of the Capoeta antalyensis and C. caelestis based on specimens examined in this study.

\begin{tabular}{|c|c|c|c|c|c|}
\hline \multicolumn{2}{|c|}{ Catalog number } & Sampling sites & Coordinates & $\mathbf{N}$ & Sampling date \\
\hline & \multicolumn{5}{|c|}{ Capoeta caelestis } \\
\hline \multirow{13}{*}{ 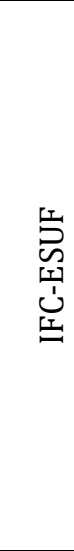 } & $03-0018$ & Göksu River at Yelmez & $37.039444,32.616111$ & 4 & 10.10 .2004 \\
\hline & $03-0084$ & Göksu River at Hamamköy- & $36.631389,33.367778$ & 12 & 26.06 .2012 \\
\hline & 03-0020 & Göksu River at near Dülgerler & $37.029167,32.697778$ & 57 & 10.10 .2004 \\
\hline & 03-0046 & Steam Gevne at Çayarası & $36.645833,32.405000$ & 5 & 18.10 .2009 \\
\hline & $03-0003$ & Manavgat River at $7 \mathrm{~km}$ northeast Manavgat & $36.830556,31.504167$ & $\mathrm{~N}$ & 14.10.1995 \\
\hline & $03-0006$ & Stream Karpuz at Haciobası & $36.728889,31.593333$ & 9 & 25.05 .1995 \\
\hline & $03-0028$ & Stream Alara at Çakallar & $36.693611,31.724444$ & 4 & 13.10 .1995 \\
\hline & $03-0047$ & Stream Ilıca -at Ilıca & $36.818611,31.353056$ & 2 & 02.05 .2009 \\
\hline & 03-0044 & Stream Dragon (Anamur)-at Alaköprü & $36.175833,32.895000$ & 13 & 17.06.2008 \\
\hline & $03-0045$ & Stream Karpuz at Hacıobası & $36.728889,31.593333$ & 2 & 18.10 .2009 \\
\hline & $03-0048$ & Stream Kaledran at Anıtlı & $36.123333,32.584444$ & 4 & 17.06 .2008 \\
\hline & 03-0114 & Stream Kargı at northern Türkler & $36.624940,31.813196$ & 5 & 18.06.2008 \\
\hline & 03-0120 & Stream Kargı at northern Türkler & $36.624940,31.813196$ & 4 & 15.10 .1995 \\
\hline \multirow{4}{*}{$\begin{array}{l}\frac{\text { r }}{\underline{T}} \\
\end{array}$} & 1962 & Stream Güneybahșiş at Güneybahșiș & $36.185000,32.859000$ & 27 & 24.03 .2019 \\
\hline & 1964 & Stream Sapadere at north of Beyreli & $36.465007,32.237990$ & 7 & 25.03 .2019 \\
\hline & 1965 & Kaledran Çayı western Anıtlı & $36.122000,32.570000$ & 6 & 26.03 .2019 \\
\hline & 1966 & Göksu River at 5 km southeast Silifke & $36.346611,33.980613$ & 10 & 24.03 .2019 \\
\hline
\end{tabular}

Kaya C, et al. New Data on the Distribution and Conservation Status of 


\section{International Journal of Zoology and Animal Biology}

\begin{tabular}{|c|c|c|c|c|c|}
\hline & 1967 & Stream Dim at west of Üzümlü & $36.572002,32.182004$ & 8 & 25.03 .2019 \\
\hline & 1922 & Göksu River at Yağcl & $37.042117,32.625608$ & 8 & 10.10 .2004 \\
\hline & 1943 & Göksu River at Göksu & $36.769517,33.183086$ & 14 & 10.11 .2016 \\
\hline & \multicolumn{5}{|c|}{ Capoeta antalyensis } \\
\hline \multirow{10}{*}{ 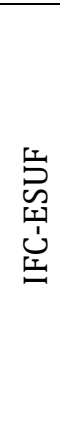 } & $03-0007$ & Köprüçay River & $37.741944,31.025556$ & 13 & 15.10 .2003 \\
\hline & 03-0008 & Köprüçay at west of Sağırin & $37.010278,31.205556$ & 6 & 18.05.1996 \\
\hline & $03-0009$ & Köprüçay, at Bașpınar & $37.833056,31.108889$ & 6 & 15.05 .1996 \\
\hline & 03-0010 & Kayaburnu bridge at Kayaburnu & $36.926881,31.022211$ & 2 & 31.05 .1998 \\
\hline & 03-0011 & Köprüçay River at Çaltepe, & $37.302222,31.190833$ & 4 & 15.09 .1996 \\
\hline & $03-0029$ & Köprüçay River at Başpınar & $37.833056,31.108889$ & 9 & 15.10 .2003 \\
\hline & $03-0030$ & Stream Boğa at Antalya & $36.865556,30.618611$ & 1 & 09.05 .2004 \\
\hline & $03-0031$ & Stream Kovada (Aksu) at southwest of Așağıgökdere & $37.576785,30.812212$ & 23 & 20.08 .2014 \\
\hline & $03-0040$ & Köprüçay River at Değirmenözü & $37.385556,31.225278$ & 1 & 19.06 .2008 \\
\hline & $03-0113$ & Stream Karaman at northwest of Antalya & $36.933889,30.574167$ & 4 & 22.05 .2010 \\
\hline
\end{tabular}

Table 1: Sampling sites in the studied area.

\section{Comparative Material}

Capoeta damascina: FFR 01887, 15, 102-230 mm SL; Gaziantep, Islahiye; Orontes River, stream Karasu, 07.06.2014, 36.853, 36.687. FFR 01881, 25, 74-187 mm SL; Hatay, Serinyol; Orontes River, stream Serinyol,
$07.06 .2014,36.365,36.214$.

\section{Results}

Metric and meristic characters of Capoeta antalyensis, C. caelestis and C. damascina were given in Tables $2 \& 3$.

\begin{tabular}{|c|c|c|c|c|c|c|c|c|c|}
\hline & \multicolumn{3}{|c|}{ C. antalyensis, $\mathrm{n}=18$} & \multicolumn{3}{|c|}{ C. caelestis, $\mathrm{n}=20$} & \multicolumn{3}{|c|}{ C. damascina, $\mathrm{n}=10$} \\
\hline & range & mean & SD & range & mean & SD & range & mean & SD \\
\hline Standard length (mm) & $115-199$ & 146.1 & 28.8 & $113-177$ & 130.7 & 15.4 & $148-208$ & 171.8 & 22 \\
\hline \%Standard length & & & & & & & & & \\
\hline Head length & $23.5-24.8$ & 24.1 & 0.5 & $23.5-26.2$ & 24.9 & 0.7 & $21.8-24.0$ & 23.1 & 0.7 \\
\hline Body depth at dorsal-fin origin & $23.0-25.4$ & 24.1 & 0.6 & 23.3-27.1 & 24.9 & 1 & $23.8-26.7$ & 25.2 & 0.9 \\
\hline Body depth at anal-fin origin & $17.0-18.7$ & 17.7 & 0.6 & $16.8-18.2$ & 17.5 & 0.4 & $16.1-17.3$ & 16.6 & 0.4 \\
\hline Depth of caudal peduncle & $11.1-12.2$ & 11.5 & 0.3 & 10.4-12.2 & 11.2 & 0.5 & $10.7-11.7$ & 11.2 & 0.4 \\
\hline Length of caudal peduncle & $17.0-19.0$ & 18 & 0.6 & $16.0-19.2$ & 17.9 & 0.9 & $17.5-19.1$ & 18.5 & 0.6 \\
\hline Head width at interorbital region & 11.9-13.1 & 12.6 & 0.4 & $11.8-13.8$ & 13.2 & 0.5 & $11.3-13.3$ & 12.5 & 0.7 \\
\hline Head width at nape & 14.7-16.1 & 15.3 & 0.5 & $13.7-17.0$ & 15.9 & 0.7 & 13.9-16. & 15.3 & 0.7 \\
\hline Head depth at interorbital region & $12.4-13.7$ & 13.1 & 0.4 & $12.6-14.0$ & 13.2 & 0.4 & $10.9-13.0$ & 12.3 & 0.7 \\
\hline Head depth at nape & $16.3-17.8$ & 17.1 & 0.4 & $16.7-18.6$ & 17.5 & 0.5 & $15.1-17.0$ & 16.5 & 0.6 \\
\hline Snout width & $9.4-10.6$ & 10 & 0.4 & 9.7-11.2 & 10.5 & 0.4 & $8.3-10.2$ & 9.7 & 0.7 \\
\hline Snout depth & $8.4-9.7$ & 9.2 & 0.4 & $8.9-10.2$ & 9.5 & 0.4 & $8.1-9.5$ & 9 & 0.5 \\
\hline Eye diameter & $3.7-5.2$ & 4.5 & 0.4 & $3.7-5.6$ & 5 & 0.5 & $3.4-4.4$ & 4 & 0.4 \\
\hline Snout length & $9.0-9.8$ & 9.4 & 0.3 & $9.4-10.2$ & 9.8 & 0.2 & $8.6-9.5$ & 9 & 0.3 \\
\hline Postorbital distance & $10.8-12.1$ & 11.3 & 0.4 & 10.4-12.4 & 11.2 & 0.5 & $10.5-11.7$ & 11.1 & 0.5 \\
\hline Interorbital width & $8.6-9.9$ & 9.2 & 0.4 & 8.8-10.1 & 9.5 & 0.4 & $9.1-10.5$ & 9.8 & 0.5 \\
\hline Width of mouth gape & $6.7-9.0$ & 7.9 & 0.7 & 7.3-9.7 & 8.6 & 0.7 & $5.5-8.1$ & 7 & 1 \\
\hline Length of maxillary barbel & $2.4-4.4$ & 3.6 & 0.5 & $4.0-5.7$ & 4.9 & 0.5 & $2.9-3.7$ & 3.3 & 0.3 \\
\hline Predorsal length & $49.7-52.4$ & 51.4 & 0.9 & 51.4-54.8 & 53 & 1 & 48.9-51. & 50.2 & 0.8 \\
\hline Prepelvic length & $54.0-57.0$ & 55.2 & 0.8 & $52.2-56.3$ & 54.4 & 1.2 & $51.0-54.1$ & 52.7 & 0.9 \\
\hline Postdorsal length & $35.4-39.8$ & 37.5 & 1.3 & $34.0-40.2$ & 37 & 1.9 & $37.8-41.5$ & 39.7 & 1.3 \\
\hline Preanal length & $75.7-80.1$ & 77.7 & 1.4 & 74.4-78.4 & 76.5 & 1.2 & 74.7-76. & 75.8 & 0.7 \\
\hline Distance between pectoral and anal fins & $54.4-59.2$ & 56.8 & 1.6 & $51.8-58.0$ & 54.5 & 1.4 & $52.2-57.8$ & 55.5 & 1.9 \\
\hline
\end{tabular}




\section{International Journal of Zoology and Animal Biology}

\begin{tabular}{|c|c|c|c|c|c|c|c|c|c|}
\hline Distance between pectoral and pelvic fins & $32.3-36.4$ & 33.7 & 1.2 & $30.3-34.9$ & 32 & 1.2 & $29.8-34.4$ & 31.8 & 1.7 \\
\hline Distance between pelvic and anal fins & $21.9-26.8$ & 23.9 & 1.4 & $21.4-24.5$ & 23 & 0.7 & $23.0-26.0$ & 24.9 & 1.1 \\
\hline Height of dorsal-fin & $17.4-20.3$ & 18.7 & 0.8 & $17.9-22.9$ & 20.3 & 1.2 & $19.1-23.4$ & 20.9 & 1.4 \\
\hline Length of dorsal-fin base & $12.4-13.5$ & 13 & 0.4 & $12.5-14.4$ & 13.6 & 0.6 & $13.4-15.6$ & 14.6 & 0.8 \\
\hline Length of pectoral-fin & $17.6-19.6$ & 18.6 & 0.7 & $19.0-22.8$ & 21.3 & 1.1 & $18.6-20.9$ & 19.5 & 0.7 \\
\hline Length of pelvic-fin & $15.3-17.3$ & 16.3 & 0.6 & $15.3-20.1$ & 17.8 & 1.1 & $15.9-18.6$ & 17.1 & 0.9 \\
\hline Height of anal-fin & $15.1-19.8$ & 17.7 & 1.3 & $15.5-21.7$ & 19 & 1.7 & $17.5-19.8$ & 18.6 & 0.8 \\
\hline Length of anal-fin base & $6.6-8.7$ & 7.5 & 0.6 & $6.7-8.9$ & 7.8 & 0.5 & $6.4-8.2$ & 7.3 & 0.5 \\
\hline Length of upper caudal-fin lobe & $23.3-28.4$ & 26.1 & 1.5 & $26.2-32.6$ & 29.1 & 1.3 & $24.6-28.7$ & 26.4 & 1.2 \\
\hline Length of median caudal-fin rays & $11.4-14.3$ & 13.1 & 0.5 & $11.2-12.9$ & 12.1 & 0.4 & $12.1-13.8$ & 12.8 & 0.6 \\
\hline
\end{tabular}

Table 2: Morphometry of Capoeta antalyensis, C. caelestis and C. damascina.

\section{Capoeta antalyensis (Battalgil, 1944) - Pamphylian scraper}

Capoeta antalyensis was described by Battalgil [20] as Varicorhinus antalyensis from Antalya. Karaman [21] examined the specimens belonging to this species and claimed that it is synonym of Hemigrammocapoeta kemali. In order to eliminate this uncertainty, Erkakan \& Kuru [22] compared the samples from streams Aksu and Köprüçay with $\mathrm{H}$. kemali and named them as Capoeta antalyensis [20].

The species characterized by having two pairs barbel, comparatively large scales (51-57 lateral line scales), less gill rakers on the first gill arch (14-17), a very weak last unbranched dorsal-fin ray (ossified 8-18\%) and the absence of serrae along the posterior margin of the last unbranched dorsal-fin ray (Figure 2).

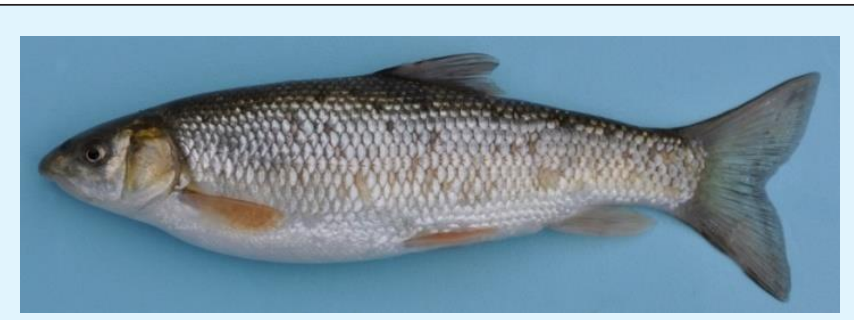

Figure 2: Capoeta antalyensis, Antalya, stream Karaman.

\section{- Distribution}

The species found from Köprüçay and Aksu rivers and streams Boğa and Gündoğdu, all around Antalya (Table 1 \& Figure 1).

\section{- Habitat}

The species prefer fast flowing rivers and larger streams with gravel or rocky substrates. However, it is also known in dam lakes on Aksu River.

\section{Capoeta caelestis Schöter, Özuluğ \& Freyhof, 2009 - Taurus scraper}

The species characterized by having 57-67 lateral line scales, one pair of barbel, 17-21 gill rakers on the first gill arch, a weak last unbranched dorsal-fin ray (ossified \% 32-50) and the absence of serrae along the posterior margin of the last unbranched dorsal-fin ray (Figure 3).

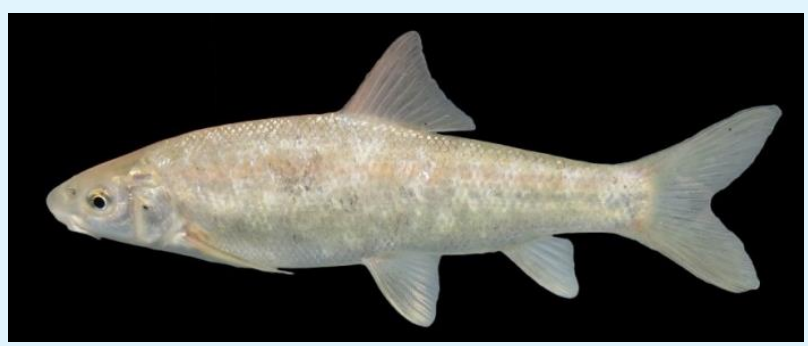

Figure 3: Capoeta caelestis, Mersin, Silifke; Göksu River.

\section{- Distribution}

Capoeta caelestis inhabits coastal stream and rivers between Alanya (Mersin) in west and Silifke (Mersin) in east (Table $1 \&$ Figure 1 ).

\section{- Habitat}

The species is generally preferring gravel substrate and often being the only fish species in its habitat.

\section{Discussion and Suggestion}

The findings of this study demonstrate that Capoeta antalyensis and Capoeta caelestis inhabits very close geographically. Capoeta caelestis is distinguished from Capoeta antalyensis by having one pair barbels (vs. two pairs), more lateral line scales (57-67, vs. 51-57) and more gill rakers on the first gill arch (17-21, vs. 14-17) (Table 3). Additionally, it was reported that there are $4.14 \%$ 


\section{International Journal of Zoology and Animal Biology}

differences in cyt b gene sequences between C. caelestis and C. antalyensis [11].

\begin{tabular}{|c|c|c|c|c|c|c|c|c|c|c|c|c|c|c|c|c|c|c|c|c|c|c|c|c|c|c|c|}
\hline & & \multicolumn{26}{|c|}{ Lateral-line scales } \\
\hline & $\mathrm{n}$ & 51 & 52 & 53 & 54 & 55 & 56 & 57 & \begin{tabular}{|l|l|}
758 \\
\end{tabular} & \begin{tabular}{|l|l|}
59 & 60 \\
\end{tabular} & 61 & 62 & 63 & 64 & 65 & 66 & 67 & 68 & 69 & 70 & 71 & 72 & 737 & 747 & 757 & & mean \\
\hline C. antalyensis & 20 & 1 & 3 & 6 & 2 & 5 & 2 & 1 & & & & & & & & & & & & & & & & & & & 53.9 \\
\hline C. caelestis & 20 & & & & & & & 1 & 1 & 14 & 2 & 4 & 3 & 3 & 1 & & & & & & & & & & & & 61.5 \\
\hline \multirow[t]{4}{*}{ C. damascina } & 16 & & & & & & & & & & & & & & & 1 & & 1 & 1 & 2 & 2 & 3 & 1 & 1 & 3 & 1 & 71.8 \\
\hline & & \multicolumn{13}{|c|}{ Transversal scales } & & & & & & & & & & & & & \\
\hline & & \multicolumn{8}{|c|}{$\begin{array}{l}\text { Between dorsal-fin and } \\
\text { lateral line }\end{array}$} & Betv & $\begin{array}{r}\text { ween } \\
\text { late }\end{array}$ & $\begin{array}{l}\text { anal } \\
\text { eral li }\end{array}$ & $\begin{array}{l}\text { I-fin } \\
\text { ine }\end{array}$ & and & \multicolumn{13}{|c|}{ Number of gill rakers } \\
\hline & $\mathrm{n}$ & 10 & 11 & 12 & 13 & \begin{tabular}{l|l}
3 & 1 \\
\end{tabular} & 14 & 15 & mean & 7 & 8 & 9 & 10 & mean & 14 & 15 & 16 & 17 & 18 & \begin{tabular}{|l|l|}
319 \\
\end{tabular} & 20 & 21 & 22 & & 24 & 25 & mean \\
\hline C. antalyensis & 20 & 2 & 13 & 5 & & & & & 11.2 & 20 & & & & 7 & 2 & 6 & 10 & 2 & & & & & & & & & 15.6 \\
\hline C. caelestis & 20 & & 10 & 7 & 3 & 3 & & & 11.7 & 13 & 7 & & & 7.4 & & & & 2 & 6 & 5 & 4 & 3 & & & & & 19 \\
\hline C. damascina & 16 & & & 2 & 9 & 9 & 4 & 1 & 13.3 & & 2 & 13 & 1 & 8.9 & & & & & & & 1 & 4 & 5 & \begin{tabular}{|l|l}
3 \\
\end{tabular} & 1 & 2 & 22.3 \\
\hline
\end{tabular}

Table 3: Frequency distribution of meristic features of the species of Capoeta antalyensis, C. caelestis and C. damascina.

There are two main habitats of Capoeta antalyensis. The first one is Aksu River which is massively polluted by household waste of Isparta city. In addition to these reservoirs there is also a regulator. Reservoirs seriously affect fish species, because they are lentic water systems. The regulator leaves the water of the river bed completely to agricultural areas. In this case, the Capoeta antalyensis population on the Aksu River is quite critical. There are two huge reservoirs in the middle section of the river which causing significant changes on the water level and habitat. Besides, these reservoirs affect the fish species seriously, because they hold water in irrigation. In this case, we can say that Capoeta antalyensis populations in the Aksu River are in quite critical.

The second river is Köprüçay which is faced with environmental pollution in upper part. However, the situation seems to be slightly better than Aksu River. In recent years, because of the activities of marble and quarry cement-derived substances are mixed with the river. These activities have led to mass fish deaths in the river several times. The habitat between the Köprülü canyon and the DSİ Aspendos regulator remains a suitable habitat for Capoeta antalyensis.

Freyhof [23] emphasized the situation of the both Aksu and Köprüçay. Accordingly, he assessed the conservation status of the species as Vulnerable. However, our recent observation in the field shows that the situation is worse and -at least for now- there is not any solution to protect the species. Therefore, we are recommending moving conservation status of the species from Vulnerable to Endangered.

Freyhof [23] mentioned that several populations of $C$. antalyensis seem to be impacted by (natural) hybridization with Capoeta caelestis. Geiger, et al. [17] supported this opinion with molecular data. This opinion triggered us to compare the specimens accordingly. Our comparisons show that all of populations located west of stream Gündoğdu (36.850182, 31.290019) belong to Capoeta antalyensis. It has been observed that there are some variations in terms of meristic features (such as lateral line scales and number of barbels which are diagnostically important for the both species in the region) among the specimens which are distributed in the region between Ilıca and Kargı streams. In order to solve this problem exactly, detailed morphological and molecular studies are needed.

Freyhof [24] emphasized that Capoeta caelestis is relatively resistant against most threats despite it has a relatively small distribution range. Besides, he remarked that the species has more than 10 independent populations and it is not believed to has declined fast enough to qualify for a threat category or "Near Threatened". Therefore, he assessed the conservation status of the species as "Least Concern". In this study, we found the species from 18 different locations and at least 12 independent water sources. Our findings very similar to the result of Freyhof [24]. Therefore, we agree about the conservation status of the species as "Least Concern" by following Freyhof [24]. 


\section{International Journal of Zoology and Animal Biology}

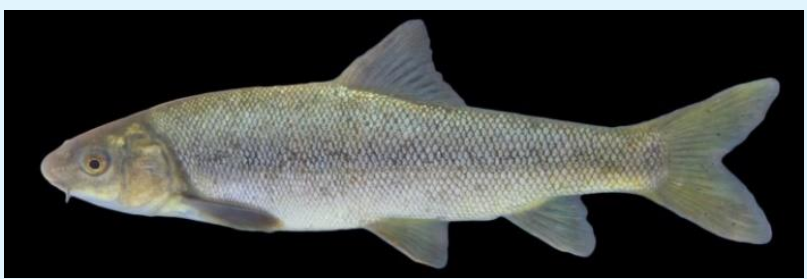

Figure 4: Capoeta damascina, Gaziantep, Orontes River, stream Karasu.

Özdemir [10] claimed that Capoeta caelestis is taxonomically close to C. damascina (Figure 4) and there is confusion in the taxonomic situation of this species. According to our comparison, Capoeta caelestis is distinguished from C. damascina by having weaker last unbranched dorsal-fin ray (ossified $32-50 \%$, vs. 50-75\%) and the absence of serrae along the posterior margin of it (vs. presence). Besides, C. caelestis has less lateral line scales than $C$. damascina (57-67, vs. 66-76), less scale rows between lateral line and anal fin origin (7-8, vs. 8-12) and fewer gill rakers on the first gill arch (17-21, vs. 20-25) (Table 3). Additionally, it was reported that there are $2 \%$ differences in cyt b gene sequences between $C$. caelestis and C. damascina [11].

These results show that the both species are well separated from each other by both molecular and morphological data. Therefore, there is not any confusion about the validity of $C$. caelestis as Özdemir [10] mentioned.

\section{Acknowledgment}

We thank to Salim Serkan Güçlü (Isparta) and Züleyha Akpınar (Rize) for their help during the fieldworks, Esra Bayçelebi (Rize) for producing the distribution map for us. This work was supported by the Recep Tayyip Erdoğan University Scientific Research Projects Coordination Unit (Project No: 2015.53002.103.01.06).

\section{References}

1. Turan D, Kottelat M, Ekmekci FG, Imamoglu HO (2006) A review of Capoeta tinca, with descriptions of two new species from Turkey (Teleostei: Cyprinidae). Rev Suisse Zool 113: 421-436.

2. Turan D, Kottelat M, Kırankaya SG, Engin S (2006) Capoeta ekmekciae, a new species of cyprinid fish from northeastern Anatolia (Teleostei: Cyprinidae). Ichthyol Explor Fres 17(2): 147-156.

3. Turan D, Kottelat M, Ekmekci FG (2008) Capoeta erhani, a new species of cyprinid fish from Ceyhan River, Turkey (Teleostei: Cyprinidae). Ichthyol Explor Fres 19(3): 263-270.

4. Turan D, Kucuk F, Kaya C, Guclu SS, Bektas Y (2017) Capoeta aydinensis, a new species of scraper from southwestern Anatolia, Turkey (Teleostei: Cyprinidae). Turk J Zool 41: 436-442.

5. Turan C (2008) Molecular systematics of Capoeta (Cyprinidae) species complex inferred from mitochondrial 16S rDNA sequence data. Acta Zool Crac 51(1-2): 1-14.

6. Ozuluğ M, Freyhof J (2008) Capoeta turani, a new species of barbel from River Seyhan, Turkey (Teleostei: Cyprinidae). Ichthyol Explor Fres 19: 289296.

7. Schöter C, Özuluğ M, Freyhof J (2009) Capoeta caelestis, a new species from Göksu River, Turkey (Teleostei: Cyprinidae). Ichthyol Explor Fres 20(3): 229-236.

8. Kucuk F, Turan D, Sahin C, Gulle I (2009) Capoeta mauricii n. sp., a new species of cyprinid fish from Lake Beysehir, Turkey (Osteichthyes: Cyprinidae). Zool Middle East 47: 71-82.

9. Levin BA, Freyhof J, Lajbner Z, Perea S, Abdoli A, et al. (2012) Phylogenetic relationships of the algae scraping cyprinid genus Capoeta (Teleostei. Cyprinidae). Mol Phylogenet Evol 62(1): 542-549.

10. Ozdemir F (2013) Capoeta in Turkey (Teleostei: Cyprinidae) Classical and Molecular Systematics Methods of Using Revision of the genus species and subspecies. PhD Thesis. Hacettepe University, Institute of Science and Technology, Ankara. Türkiye pp: 157.

11. Bektas Y, Turan D, Aksu I, Ciftci Y, Eroglu O, et al. (2017) Molecular phylogeny of the genus Capoeta (Teleostei. Cyprinidae) in Anatolia, Turkey. Biochem Syst Ecol 70: 80-94.

12. Bektas Y, Aksu I, Kaya C, Turan D (2019) DNA barcoding of the Genus Capoeta (Actinopterygii: 


\section{International Journal of Zoology and Animal Biology}

Cyprinidae) from Anatolia. Turk J Fish Aquat Sc 19(9): 739-752.

13. Elp M, Osmanoglu MI, Kadak AE, Turan D (2018) Characteristics of Capoeta oguzelii, a new species of cyprinid fish from the Ezine Stream, Black Sea basin, Turkey (Teleostei: Cyprinidae). Zool Middle East 64: 102-111.

14. Kaya C (2019) Taxonomic Revision of the Genus Species Belong to Genus Capoeta Distributed in Turkey. PhD Thesis. Recep Tayyip Erdogan University, Institute of Science and Technology, Rize, Turkey pp: 126.

15. Alwan N (2010) Systematics, taxonomy, phylogeny and zoogeography of the Capoeta damascina species complex (Pisces: Teleostei: Cyprinidae) inferred from comparative morphology and molecular markers. Unpublished $\mathrm{PhD}$ Thesis Dissertation. Johann Wolfgang Goethe-Universita"t, Frankfurt am Main pp; 264.

16. Alwan N, Esmaeili HR, Krupp F (2016) Molecular phylogeny and zoogeography of the Capoeta damascina species complex (Pisces: Teleostei: Cyprinidae). Plos One 11(6): 1-25.

17. Geiger MF, Herder F, Monaghan MT, Almada V, Barbieri R, et al. (2014) Spatial heterogeneity in the
Mediterranean Biodiversity Hotspot affects barcoding accuracy of its freshwater fishes. Mol Ecol Resour 14(6): 1210-1221.

18. Kucuk F, Guclu SS (2006) Capoeta antalyensis (Battalgil, 1944) (Pisces: Cyprinidae)'in yayılış alanı ve taksonomik özelliklerinin karşılaştırılması. J Fish Aqua Sc 23(3-4): 251-256.

19. Kottelat M, Freyhof J (2007) Handbook of European freshwater fishes. In: Kottelat, Cornol, Freyhof, Berlin, et al. pp: 646.

20. Battalgil F (1944) New Fish Species from Inlandwaters. Istanbul University, Basımevi, Turkey pp: 126-133.

21. Karaman MS (1971) Freshwaters of Turkey, 8. Parts: Revision of Barbus Genus from North Africa, Middle East and Europa. Mit Hamburg Zoo Mus İnst Band 67: 175-254.

22. Erk'akan F, Kuru M (1983) Re-discussion of Systematical Status of Varicorhinus antalyensis Battalgil, 1944. Hacettepe Bull Nat Sci Eng 12: 49-65.

23. Freyhof J (2014) Capoeta antalyensis. The IUCN Red List of Threatened Species 2014.

24. Freyhof J (2014) Capoeta caelestis. The IUCN Red List of Threatened Species 2014. 